\title{
Pathogenesis of Chronic Wasting Disease in Cervidized Transgenic Mice
}

Davis M. Seelig, ${ }^{\star}$ Gary L. Mason, ${ }^{\dagger}$ Glenn C. Telling, ${ }^{\dagger}$ and Edward A. Hoover*

From the Departments of Microbiology, Immunology, and Pathology,* Colorado State University, Fort Collins, Colorado; and the Department of Microbiology, Immunology, and Molecular Genetics, ${ }^{\dagger}$ University of Kentucky, Lexington, Kentucky

Chronic wasting disease (CWD) is a fatal, endemic prion disease of wild and captive cervids, including deer, elk, and moose. Typical of prion diseases, CWD is characterized by the conversion of the native, protease-sensitive protein $\operatorname{PrP}^{\mathrm{C}}$ to a protease-resistant isoform, denoted as $\operatorname{PrP}^{\mathrm{RES}}$. Here we have studied the expression of cervid $\operatorname{PrP}^{\mathrm{C}}$ and the pathogenesis of CWD infection in transgenic mice expressing the normal cervid prion protein ( $\mathrm{Tg}[\mathrm{CerPrP}]$ mice). Using tissue-based in situ immunohistochemistry protocols, we first identified cervid $\operatorname{Pr}^{\mathrm{C}}$ expression in the lymphoid, nervous, hemopoietic, endocrine, and certain epithelial tissues of $\mathrm{Tg}[\mathrm{CerPrP}]$ mice. $\mathrm{Tg}[\mathrm{Cer}-$ PrP] mice were then inoculated with CWD via one of four routes (intracerebral, intravenous, intraperitoneal, or oral); all groups developed spongiform encephalopathy, although the oral route required a larger infecting dose. Incubation periods were $184 \pm$ $13,218 \pm 15,200 \pm 7$, and $350 \pm 27$ days after inoculation, respectively. In longitudinal studies, we tracked the appearance of $\operatorname{PrP}^{\mathrm{RES}}$ in the brain, spleen, Peyer's patches, lymph nodes, pancreatic islets of Langerhans, bone marrow, and salivary glands of preclinical and terminal mice. In addition, we documented horizontal transmission of CWD from inoculated mice and to un-inoculated cohabitant cage-mates. This work documents the multiroute susceptibility, pathogenesis, and lateral transmission of CWD infection in $\mathrm{Tg}[\mathrm{CerPrP}]$ mice, affirming this model as a robust system to study this cervid transmissible spongiform encephalopathy. (Am J Pathol 2010, 176:2785-2797; DOI: 10.2353/ajpath.2010.090710)

The transmissible spongiform encephalopathies (TSEs), or prion diseases, are uniformly fatal, chronic, and pro- gressive neurodegenerative diseases that affect humans (Kuru and Creutzfeldt-Jakob disease), sheep and goats (scrapie), cattle (bovine spongiform encephalopathy), felids (feline spongiform encephalopathy), and cervids (chronic wasting disease [CWD]). Prion diseases are so named on the basis of their association with aggregates of conformationally altered and post-translationally modified isoforms (denoted PrPRES) of the normal cellular prion protein (denoted $\mathrm{PrP}^{\mathrm{C}}$ ). CWD was first recognized in captive mule deer in Colorado in 1967 and subsequently identified as a TSE affecting captive and wild cervids including mule deer, white-tailed deer, elk, and moose. CWD is unique among TSEs in infecting freeranging wildlife species and in its highly transmissible nature. ${ }^{1}$ Although the mechanism(s) of this facile spread remain uncertain, experimental and epidemiological evidence suggests lateral transmission via saliva, urine, and feces. ${ }^{2-4}$

Although mice of Mus species are substantially resistant to CWD infection, FVB mice engineered to express the normal cervid prion protein $\left(\mathrm{PrP}^{\mathrm{C}}\right)$ transgenically (ie, cervidized mice, $\mathrm{Tg}[\mathrm{CerPrP}]$ mice) have been shown to be susceptible to CWD infection by intracerebral inoculation. ${ }^{5-10}$ In the present study we used a series of immunohistochemical $(\mathrm{IHC})$ techniques to i) map the distribution of $\mathrm{PrPC}^{\mathrm{C}}$ in naive $\mathrm{Tg}[\mathrm{Ce} \mathrm{PrP}]$ mice, ii) determine the CWD susceptibility of these mice after exposure via a presumed natural route (p.o.) and three parenteral routes (i.v., i.p., and intracerebral [i.c.]), iii) assess the longitudinal accumulation of PrPRES in tissues of inoculated mice, and iv) evaluate the possibility of CWD horizontal transmission to naive, cohabitating mice, thereby simulating lateral transmission in the native cervid host.

Supported by National Institute of Allergy and Infectious Diseases (grant N01-Al25491) and National Center for Research Resources (grant T32-RR07072).

Accepted for publication February 18, 2010.

Address reprint requests to Edward A. Hoover, D.V.M., Ph.D., Colorado State University, Department of Microbiology, Immunology, and Pathology, 1619 Campus Delivery, Fort Collins, CO 80523. E-mail: edward.hoover@ colostate.edu. 


\section{Materials and Methods}

\section{Ethics Statement}

The animal experiments were conducted under the guidelines developed by the Colorado State University Animal Care and Use Committee.

\section{Generation and Genotyping of Tg[CerPrP] Mice}

The transgenic mice used in this study (1536 Tg[CerPrP] mice) were created and their susceptibility to CWD was established in the Telling laboratory. ${ }^{6}$ Line 1536 was generated as follows: the open reading frame cassette of the CerPrP S2 allele (GenBank accession no. AF009180) was released from plasmid sequences after digestion with Sall and Xhol, and purified open reading frame fragments were ligated to the Sall-cut cosSHa.Tet cosmid expression vector. The cosSHa.Tet cosmid expression vector contains a 49-kb DNA fragment encompassing the Syrian hamster PrP gene and has been used to produce numerous Tg models of prion diseases, including mice in which the species barriers to Syrian hamster, human, and bovine prions were eliminated. ${ }^{5,6,11-16}$ To increase CerPrP expression in transgenic mice, the CerPrP S2 allele plasmid nucleotide sequence was modified by site-directed mutagenesis immediately upstream of the initiating ATG to produce a consensus Kozak translation initiation sequence. Two founders were generated by microinjection of fertilized embryos from Prnp ${ }^{0 / 0}$ knockout mice on an FVB/N background (FVB/Prnp ${ }^{\mathrm{O} / 0}$ ), from which a colony of $1536 \mathrm{Tg}[\mathrm{CerPrP}]$ mice was developed. Tail-tip DNAs were screened for the presence and appropriate orientation of the CerPrP transgene by conventional and real-time $\mathrm{PCR}^{6}{ }^{6}$ The $\mathrm{PrP}^{\mathrm{O} / 0}$ mice used in the $\mathrm{PrP}^{\mathrm{C}}$ mapping studies were kindly donated by Dr. Mark Zabel at Colorado State University (Fort Collins, CO).

\section{Inoculum Preparation}

The CWD inoculum (D-10) was prepared as a brain homogenate derived from a terminally ill, naturally infected mule deer (Dr. Michael Miller, Colorado Division of Wildlife, Wildlife Research Center, Fort Collins, CO). This inoculum has proven to be infectious for both deer and the intracerebrally inoculated $1536 \mathrm{Tg}[\mathrm{CerPrP}]$ mice in previous studies. ${ }^{6,17}$ The negative control inoculum consisted of a brain homogenate from a CWD-negative white-tailed deer originating outside of the CWD endemic area (courtesy of David Osborn, Warnell School of Forestry, University of Georgia, Athens, GA). Both inocula were homogenized in sterile PBS using a reciprocal homogenizer and diluted to a final concentration of $1 \%(\mathrm{w} / \mathrm{v})$ using sterile PBS-containing penicillin-streptomycin (100 U/ml).

\section{Inoculation Protocol}

Five experimental groups of $1536 \mathrm{Tg}[\mathrm{CerPrP}]$ mice $(n=$ 10 per group) were used in these studies. Four of the groups consisted of 4- to 6-week-old, mixed-sex, Tg[Cer$\mathrm{PrP}]$ mice inoculated with CWD prions via one of four routes: i.c., i.p., i.v., or p.o. The fifth group consisted of age- and sex-matched, naive Tg[CerPrP] mice included to assess the possibility of horizontal transmission (described below). In each cage, two inoculated mice were housed with one sentinel, noninoculated mouse. For i.c. inoculation, mice were sedated through the i.p. injection of a mixture of ketamine (120 mg/kg) and xylazine (16 $\mathrm{mg} / \mathrm{kg}$ ). Mice were inoculated with $30 \mu \mathrm{l}$ of a $1 \%$ brain homogenate via a 29-gauge needle in the left parietal lobe of the cerebral cortex. For i.p. inoculation, $100 \mu$ l of a $1 \%$ brain homogenate was injected via a 29-gauge needle into the right caudal ventral abdomen. For i.v. inoculation, $30 \mu \mathrm{l}$ of a $1 \%$ brain homogenate was injected through either the left or right tail vein. Oral inoculations were performed by oral instillation of $50 \mu \mathrm{l}$ of a $1 \%$ brain homogenate administered on each of 2 consecutive days. Mice were not sedated for the i.p., i.v., or p.o. inoculations. A second oral inoculation study used whole brain and is described separately below. Negative control mice ( $n=6$ per route) were inoculated by all routes above with $1 \%$ brain homogenate obtained from a CWDnegative white-tailed deer.

\section{Animal Evaluation, Euthanasia, and Necropsy}

After inoculation, Tg[CerPrP] mice were sacrificed at either i) a predetermined time point or ii) at the onset of the terminal neurological disease. The criteria used for the diagnosis of central nervous dysfunction in prion-inoculated mice have been published previously ${ }^{18}$ and consist of severe ataxia, difficulty in righting from a supine position, tail rigidity, generalized tremors, and/or severe mental obtundation. Tg[CerPrP] mice sacrifice time points were chosen using the previously reported 220-day survival period after i.c. inoculation ${ }^{6}$ and were as follows: 60 days postinoculation (dpi), 120 dpi, 180 dpi, 240 dpi, and terminal disease. In contrast, the sentinel, cohabitant mice were euthanized at either the onset of terminal neurological disease or other clinical disease necessitating humane euthanasia.

At each predetermined sacrifice point, three mice per inoculation group were euthanized (two mice from the CWD-inoculated group and one mouse from the shaminoculated group) for a total of 12 mice at each time point. One of the two mice from each CWD-inoculated group was perfusion-fixed with paraformaldehyde-lysine-periodate (PLP) fixative and necropsied. The second mouse from this group and the single sham-inoculated mouse were euthanized via i.p. injection of pentobarbital (Sleepaway, Fort Dodge Animal Health, Fort Dodge, IA) and necropsied. Tissues from this group were split between frozen storage (at $-80^{\circ} \mathrm{C}$ ) and PLP immersion fixation. At necropsy, samples from all tissues were obtained, including both nervous (brain and spinal cord) and non-nervous (peripheral) tissues. After necropsy, all fixed tissues were immersed in PLP fixative for 24 hours before being moved into $70 \%$ ethanol for long-term storage. After less than 5 days in ethanol, tissues were routinely trimmed for histological processing. Whole brains were sectioned coronally to generate a series of 2- to 3-mm thick tissue 
slices, representing the following regions of the brain: i) neocortex (at the level of the caudate nucleus), ii) hippocampus and hypothalamus, iii) midbrain (at the level of the colliculi); iv) hindbrain (including the pons and the cerebellum), and v) caudal brainstem (at the level of the obex).

\section{Tissue Collection and Processing}

For detection of $\mathrm{PrP}^{\mathrm{C}}, \mathrm{Tg}[\mathrm{CerPrP}]$ and $\mathrm{PrP}^{\mathrm{O} / \mathrm{O}}$ mice were perfusion or immersion fixed with one of two fixatives: $10 \%$ neutral buffered formalin or PLP. In all cases, perfusion fixation was performed with a commercially available, gravity-feed system (AutoMate Scientific) and modification of a published protocol, which uses left ventricular fixative injection and right atrial exsanguination. ${ }^{19}$ After perfusion, tissues were postfixed in their respective fixative for 12 to 24 hours and transferred to $70 \%$ ethanol for long-term storage. For detection of PrPRES, tissues were perfusion-fixed with PLP as described above. To ablate $\mathrm{PrP}^{\mathrm{C}}$ immunoreactivity, cassetted tissues were immersed in $88 \%$ formic acid for 1 hour and then rinsed in running tap water for 1 hour before histological processing.

\section{Histology and Immunohistochemistry}

For all experiments, paraffin-embedded tissue sections (6 $\mu \mathrm{m}$ ) were mounted onto positively charged glass slides and deparaffinized in an oven followed by successive xylene immersions in and rehydrated through graded ethanol. To enhance detection, tissues were subjected to heat-induced epitope retrieval using an automated antigen-retrieval system (Retriever) and a proprietary buffer solution (Target Retrieval Solution, DakoCytomation, Carpinteria, CA).

For the detection of $\mathrm{PrP}^{\mathrm{C}}$, tissues were stained using an automated immunostainer (DakoCytomation), the primary prion protein antibody R505.5 (rabbit polyclonal, a generous gift from Dr. Jan Langeveld, Central Veterinary Institute of Wageningen University, Wageningen, The Netherlands), and a horseradish peroxidase (HRP)-conjugated anti-rabbit secondary antibody. (The R505.5 antibody was elicited in rabbits by immunization with the ovine prion protein peptide 100 to 111 [SQWNKPSKPKTN]. The reactivity and specificity of this antibody for prion protein have been demonstrated by Pepscan, Western blot, enzyme-linked immunosorbent assay, and radio-immunoprecipitation. ${ }^{20}$ ) Antibody deposition was visualized using the chromogen diaminobenzidine (DakoCytomation); slides were counterstained with hematoxylin and incubated with a bluing reagent ( $0.1 \%$ sodium bicarbonate). After immunostaining, slides were dehydrated through graded ethanol, cleared with xylene, and coverslipped.

For detection of PrPRES, an $\mathrm{IHC}$ protocol that combined either a one- or two-step immunostaining procedure with tyramide signal amplification (TSA) was used. Previous work in our laboratory has shown that this methodology is more sensitive in the detection of PrPRES than traditional, two-step indirect IHC protocols. ${ }^{21}$ The TSA-PrPRES proto- col used a proprietary TSA detection kit (PerkinElmer Life and Analytical Sciences, Waltham, MA) and was conducted as follows. After slide rehydration and heat-induced epitope retrieval (as described above), tissue section endogenous peroxidase activity was blocked using $3 \% \mathrm{H}_{2} \mathrm{O}_{2}$ for 60 minutes. Sections were further blocked using a proprietary protein block (TNB, PerkinElmer Life and Analytical Sciences) for 60 minutes and 10\% goat serum for 30 minutes. (Slides were incubated with one of two anti-prion antibodies, either the R505.5 antibody or the HRP-conjugated antibody BAR-224. The BAR-224 antibody [Cayman Chemicals, Ann Arbor, MI] is a monoclonal prion protein antibody raised against amino acids 141 to 151 of the ovine prion protein.)

In protocols incorporating the R505.5 antibody, slides were incubated with a HRP-conjugated anti-rabbit Ig secondary antibody. Between all incubation steps, slides were washed three times ( 5 minutes each) in a TNT wash buffer $(0.1 \mathrm{M}$ Tris- $\mathrm{HCl}, \mathrm{pH} 7.5,0.15 \mathrm{M} \mathrm{NaCl}$, and $0.05 \%$ Tween 20). After application of the antibodies, slides were sequentially incubated with two proprietary TSA reagents: i) dinitrophenol (DNP) amplification reagent (PerkinElmer Life and Analytical Sciences) for 4 minutes and ii) anti-DNP-HRP (PerkinEImer Life and Analytical Sciences) for 30 minutes. Antibody deposition was visualized using diaminobenzidine, and slides were counterstained with hematoxylin and incubated with a bluing reagent ( $0.1 \%$ sodium bicarbonate). After immunostaining, slides were dehydrated through graded ethanol, cleared with xylene, and coverslipped.

\section{Peptide-Blocking Studies}

To confirm the specificity of the anti-PrPRES- detection protocol, we conducted a series of complementary peptide-blocking $\mathrm{IHC}$ studies in which the anti-prion protein antibody BAR-224 was preincubated with the peptide FGSDYEDRYYR, which corresponds with its eliciting antigen, residues 141 to 151 of the ovine prion protein. In such peptide-blocking reactions, the monoclonal antibody was incubated with its eliciting peptide for 60 minutes at room temperature, and this monoclonal antibodypeptide solution was applied to the tissue sections after the application of the TNB protein block and the $10 \%$ goat serum block. The remainder of the immunostaining protocol was identical to that described above; however, antibody deposition was visualized using the chromogen 3-amino-9-ethyl-carbazole (DakoCytomation) rather than diaminobenzidine.

\section{Whole-Brain Oral Inoculation Studies}

As a follow-up to the p.o. inoculation studies described above, a study was initiated to determine a whether larger p.o. doses of CWD prions would affect the susceptibility of $\mathrm{Tg}[\mathrm{CerPrP}]$ mice to infection. Two groups of naive, 4 - to 6 -week-old mice ( $n=5$ per group) were orally inoculated with whole brain obtained from either a known CWD-positive or -negative white-tailed deer. Mice were orally inoculated with 0.2 to $0.25 \mathrm{~g}$ of whole-brain material 
introduced directly into the oral cavity. Mice were not sedated for this procedure as they consumed the inoculum. After inoculation, mice were monitored for the development of clinical neurological disease as described above and euthanized at the onset of either terminal neurological disease or any other severe clinical disease necessitating humane euthanasia. On euthanasia, mice were perfusion-fixed with PLP fixative, and tissues were prepared for immunohistochemical evaluation.

\section{Results}

\section{Immunohistochemical Detection of $\operatorname{Pr}^{C}$ in Naive Tg[CerPrP] Mice}

To determine the tissue-specific distribution profile of the $\mathrm{PrP}^{\mathrm{C}}$ in $\mathrm{Tg}[\mathrm{CerPrP}]$ mice, we developed IHC protocols to detect $\mathrm{PrP}^{\mathrm{C}}$ in paraffin-embedded tissues by evaluating seven primary antibodies, two fixation techniques (perfusion and immersion), and two fixatives (PLP and 10\% neutral buffered formalin). The most sensitive $\operatorname{PrP}^{\mathrm{C}}$ detection method combined perfusion fixation with PLP and the primary polyclonal antibody R505.5. Cervid $\operatorname{PrP}^{\mathrm{C}}$ expression was identified in a surprisingly wide variety of tissues, including those of the nervous, lymphoid, gastrointestinal, hemopoietic, and endocrine systems (Figure 1, Table 1). In general, the immunoreactivity was most prominent in the cytoplasm, usually as finely granular; in the central nervous system (CNS), more coarsely aggregated immunostaining was seen in the neuropil.

\section{CNS PrPC Expression}

$\mathrm{PrP}^{\mathrm{C}}$ immunoreactivity was identified in cells morphologically consistent with neurons and glia and within the neuropil (Figure 1A). In contrast, $\mathrm{PrP}^{\mathrm{C}}$ expression was not identified within components of the peripheral nervous system, including sections of peripheral nerves identified in skeletal muscle or the plexuses of the enteric nervous system.

\section{Lymphoid $\operatorname{PrP}^{C}$ Expression}

$\mathrm{PrP}^{\mathrm{C}}$ immunoreactivity was identified within the cortical germinal centers and paracortical and medullary regions, representing macrophages and/or dendritic cells of lymph nodes, spleen, thymus, and Peyer's patches (Figure $1, \mathrm{~B}$ and $\mathrm{K}$ ). In the spleen, immunoreactivity was localized to cells morphologically and microanatomically consistent with lymphocytes and macrophages and/or dendritic cells in the lymphoid nodules and the periarterial lymphatic sheaths (Figure 1B). In the thymus, immunoreactivity was confined to cortical and medullary lymphoid cells, whereas the thymic epithelial cell population was negative.

\section{Gastrointestinal $\operatorname{PrP}^{C}$ Expression}

$\operatorname{PrP}^{\mathrm{C}}$ expression was identified within a small number of cells morphologically consistent with small lymphocytes and dendritic cells throughout the alimentary canal (oral cavity, esophagus, stomach, intestine, and colon).
All remaining cell types were negative. Among the extratubular tissues of the gastrointestinal tract, including the salivary glands, tongue, liver, and exocrine pancreas, $\mathrm{PrP}^{\mathrm{C}}$ immunoreactivity was identified in the glandular epithelial cells of the salivary glands (Figure 1C), in the cells of the lingual taste buds (Figure 1J), in the resident macrophage population of the liver (Kupffer cells) (Figure $1 \mathrm{~L})$, and in the epithelial cells of the pancreatic endocrine islets (Figure 1I).

\section{Urogenital $\operatorname{PrP}^{C}$ Expression}

$\mathrm{PrP}^{\mathrm{C}}$ immunoreactivity was identified in the renal cortical tubular system, renal glomerulus (Figure 1D), testes, accessory sex glands, and ovary.

\section{Respiratory $\operatorname{PrP}^{C}$ Expression}

$\mathrm{PrP}^{\mathrm{C}}$ was detected in only a small number of cells within the interalveolar interstitium, probably either interstitial or intravascular macrophages.

\section{Endocrine $\operatorname{PrP}^{C}$ Expression}

$\mathrm{PrP}^{\mathrm{C}}$ immunoreactivity was detected in the epithelial cells of the pancreatic islets, and the adrenal, thyroid, and parathyroid glands (Figure 1I).

\section{Hematopoietic $\operatorname{PrP}^{C}$ Expression}

$\mathrm{PrP}^{\mathrm{C}}$ immunoreactivity was detected in megakaryocytes and cells of the myeloid lineage. (To confirm the specificity of the $\mathrm{PrP}^{\mathrm{C}}$ detection protocol, matching tissues from $\mathrm{PrP}^{\mathrm{O} / \mathrm{O}}$ mice were identically immunostained and in such animals, no $\operatorname{PrP}^{\mathrm{C}}$ immunoreactivity was observed [Figure 1, I-L and $U-X]$.) In addition, PrPC immunoreactivity was not identified in sections immunostained with a protocol incorporating a negative control antiserum (data not shown) or two immersions in $88 \%$ formic acid (Figure 1, E-H, M-P, and Q-T).

\section{Transmission of CWD to Tg[CerPrP] Mice}

The inoculation of the Tg[CerPrP] mice with mule deer origin CWD prions resulted in clinical disease in the i.c., i.p., and i.v. inoculated animals with the following survival periods: i.c., $184 \pm 13$ dpi; i.p., $218 \pm 15$ dpi; and i.v., $200 \pm 7$ dpi, respectively (Table 2). The clinical disease was characterized by ataxia, hyperactivity, tail rigidity, and, terminal mental obtundation. In contrast, Tg[CerPrP] mice inoculated orally with the same 1\% CWD brain homogenate remained healthy for $>700 \mathrm{dpi}$, as did all sham-inoculated controls (Table 2).

\section{Neuropathology in Inoculated Tg[CerPrP] Mice}

Independent of inoculation route, CWD-infected mice developed similar histopathological lesions. These changes, in the hippocampus, hypothalamus, cerebellum, and brainstem, consisted of raggedy rarefaction of the neuropil and 


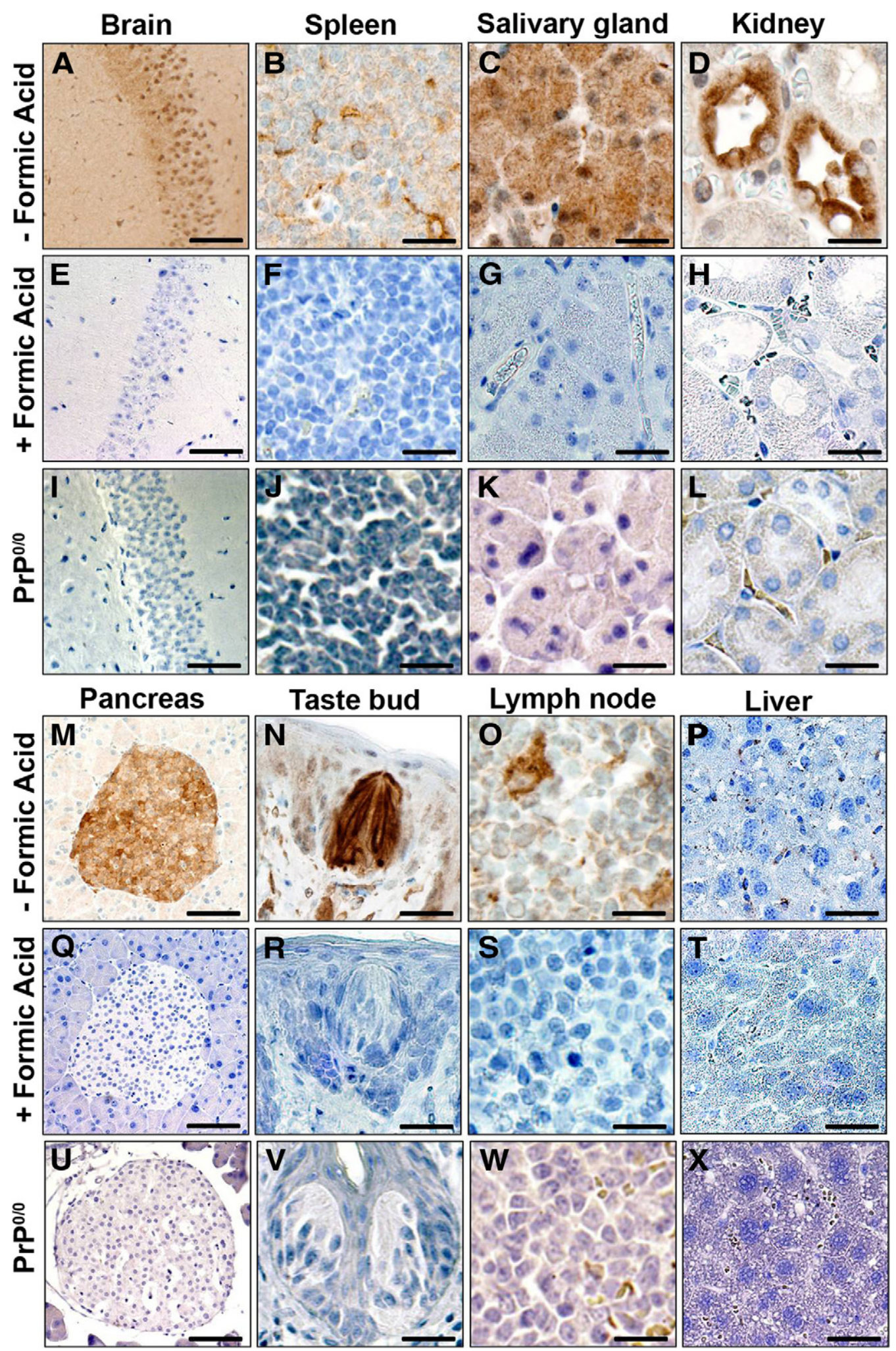

Figure 1. Cervid $\mathrm{PrP}^{\mathrm{C}}$ expression in tissues of naive $\mathrm{Tg}[\mathrm{CerPrP}]$ mice. All tissues were from PLP-perfused, noninoculated mice stained using the IHC protocol detailed in the Materials and Methods. Each of the two sets of three rows represents identical tissues that were stained with the R505.5 antibody. The middle row of each set represents tissues that have been twice treated with $88 \%$ formic acid, whereas the bottom row represents tissues from $\operatorname{PrP} / 0$ mice. Row 1: $\operatorname{PrP}$ immunoreactivity (brown) in (A) neurons and neuropil, (B) splenic nucleated cells, (C) salivary gland epithelial cells, and (D) renal tubular epithelial cells. Row 3: Mild to marked PrPC immunoreactivity (brown) in (I) pancreatic islet cells, (J) lingual taste buds, (K) lymph node nucleated cells, and (L) hepatic Kupffer cells Note the lack of $\mathrm{PrP}^{\mathrm{C}}$ immunoreactivity observed in the tissues treated with $88 \%$ formic acid (row 2, E-H, and row 5, Q-T) or in the tissues from the $\mathrm{PrP} \mathrm{P}^{0 / 0}$ mice (rows 3 and 6). Scale bars: $100 \mu \mathrm{m}(\mathbf{A}, \mathbf{E}$, and $\mathbf{I}) ; 40 \mu \mathrm{m}(\mathbf{B}, \mathbf{F}$, and $\mathbf{J}) ; 40 \mu \mathrm{m}(\mathbf{C}, \mathbf{G}$, and $\mathbf{K}) ; 30 \mu \mathrm{m}(\mathbf{D}, \mathbf{H}$, and $\mathbf{L}) ; 120 \mu \mathrm{m}(\mathbf{M}, \mathbf{Q}$, and $\mathbf{U}) ; 45 \mu \mathrm{m}(\mathbf{N}, \mathbf{R}$, and $\mathbf{V}) ; 25 \mu \mathrm{m}(\mathbf{O}, \mathbf{S}$, and $\mathbf{W}) ; 20 \mu \mathrm{m}(\mathbf{P}, \mathbf{T}$, and $\mathbf{X})$. 
Table 1. $\operatorname{PrP}^{\mathrm{C}}$ Expression in the Tissues of $1536 \mathrm{Tg}[\mathrm{CerPrP}]$ Cervidized Transgenic Mice as Determined by Immunohistochemical Analysis

\begin{tabular}{|c|c|c|c|}
\hline \multicolumn{2}{|l|}{ Central nervous svstem } & \multicolumn{2}{|l|}{ Urogenital system } \\
\hline Neuronal cell bodies & Positive & Renal tubules & Positive \\
\hline Oligodendrocytes & Negative & Glomerulus & Positive \\
\hline Astrocytes & Negative & Urinary epithelium & Negative \\
\hline Neuropil & Positive & Prostate & Positive \\
\hline Ependymal cells & Positive & Vesicular gland & Positive \\
\hline Peripheral nervous system & & Coagulating gland & Negative \\
\hline Ganglion neuronal cell bodies & Negative & Testes & Positive \\
\hline Axons & Negative & Uterine endometrium & Negative \\
\hline Cardiovascular system & & Vaginal epithelium & Negative \\
\hline Cardiac myocytes & Negative & Ovary & Positive \\
\hline Endothelial cells & Positive & Respiratory system & \\
\hline Lymphoid system & & Respiratory epithelium & Negative \\
\hline Lymph node cortical follicles & Positive & Type I pneumocytes & Negative \\
\hline Lymph node paracortex & Positive & Type II pneumocytes & Negative \\
\hline Lymph node medulla & Positive & Alveolar macrophages & Positive \\
\hline Splenic lymphatic sheaths & Positive & Endocrine system & \\
\hline Thymus & Positive & Pancreatic islet cells & Positive \\
\hline Gastrointestinal system & & Adrenal medullary cells & Positive \\
\hline Salivary glands & Negative & Adrenal cortical cells & Positive \\
\hline Tongue epithelium & Negative & Thyroid epithelium & ND \\
\hline Taste buds & Positive & Parathyroid epithelium & ND \\
\hline Esophagus & Negative & Other tissues & \\
\hline Gastric epithelium & Negative & Myocytes & Negative \\
\hline Submucosal glands & Negative & Bone marrow & Positive \\
\hline Peyer's patches & Positive & Adipose tissue & Negative \\
\hline Enterocytes & Negative & Keratinocytes & Negative \\
\hline Pancreatic exocrine cells & Negative & Hair follicles/adnexae & Negative \\
\hline Liver (hepatocytes) & Negative & Bone marrow & Positive \\
\hline Liver (nonhepatocytes) & Positive & Osteocytes, osteoclasts, and chondrocytes & Negative \\
\hline
\end{tabular}

All tissues were obtained from PLP perfusion-fixed, adult $1536 \mathrm{Tg}[\mathrm{CerPrP}]$ mice and stained using the R505.5 primary antibody and the IHC protocol detailed in the text. In the tissues denoted as positive, $\operatorname{PrP}^{\mathrm{C}}$ immunoreactivity varied in intensity, but the reactivity was uniformly cytoplasmic and granular in nature.

$\mathrm{ND}$, not done.

perikaryon (spongiform degeneration) with the adjacent deposition of pale eosinophilic plaques. The most extensive lesions were identified in the cellular layers of the hippocampus and the cerebellum. In the cerebellum, there was extensive neuronal loss within the Purkinje cell and granular layers with rarefaction of the neuropil and plaque accumulation (Figure 2A). Likewise in the hippocampus, there was loss of neurons within cellular layers as well as neuropil rarefaction and eosinophilic plaque accumulation (Figure $2 \mathrm{C})$. No lesions were observed in sham-inoculated Tg[CerPrP] mice (Figures 2, B and D).

\section{$\operatorname{PrP}^{R E S}$ Distribution in Tg[CerPrP] Mice}

In mice successfully infected by each of the three routes, PrPRES depositions differed chiefly in the sequence of first detection in target organs and cell populations and, in some instances as noted, in the spectrum of PrPRES positive cell phenotype (Figure 3). The earliest detection of PrPRES in the CNS was at $60 \mathrm{dpi}$, in the gray and white matter of the frontal cortex, the hippocampus, and the hypothalamus, most commonly in regions of neuropil spongiosis (Figure 4A). The earliest detection of PrPRES in a peripheral tissue was at $60 \mathrm{dpi}$ in the spleen, liver, and mesenteric lymph nodes. In the spleen, the PrPRES appeared as granular deposits suggestive of cytoplasmic processes of follicular dendritic cells in lymphoid follicles (Figure 4B). In the liver, the PrPRES was detected in angular-shaped, sinusoidal-lining cells suggestive of Kupffer cells (Figure 4C). In all lymphoid tissues, PrPRES was detected in a small number of cells within the lym-

Table 2. Transmission of CWD Prions to Transgenic Mice After Multiroute Inoculation

\begin{tabular}{lcccccc}
\hline & \multicolumn{5}{c}{ Route of inoculation } \\
\cline { 2 - 6 } & i.c. & i.p. & i.v. & p.o. 1\% & Contact & p.o. WB \\
\hline Days to disease & $184 \pm 13$ & $218 \pm 15$ & $200 \pm 7$ & NA & See text & $350 \pm 27$ \\
No. mice with TSE/total no. mice & $3 / 3$ & $3 / 3$ & $3 / 3$ & $0 / 10$ & $3 / 20^{*}$ & $3 / 5$ \\
\hline
\end{tabular}

Time to clinical disease and number of mice evaluated at the time of terminal disease are represented for the i.c., i.p., i.v., and p.o. inoculated 1536 $\mathrm{Tg}[\mathrm{CerPrP}]$ mice. The results of two p.o. inoculation studies are summarized: one performed with a 1\% inoculum (p.o. 1\%) and the second with a whole-brain (p.o. WB) inoculum (see text for details). The contact transmission mice represent naïve transgenic mice, which were cohabitant with inoculated counterparts (see text for details). For all animals, CWD infectivity was confirmed by IHC. None of the sham-inoculated mice $(n=6$ per route) developed clinical neurological disease nor demonstrated PrPRES accumulations in the brain. *In the contact transmission group, only 15 of these 20 mice were observed beyond 600 dpi of cage-mates.

NA, not applicable. 


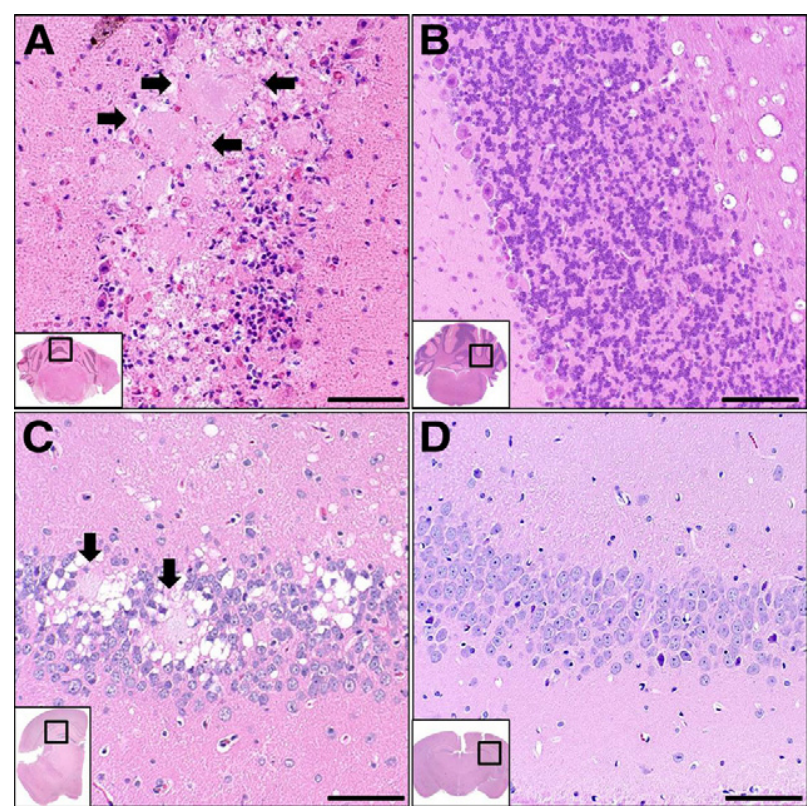

Figure 2. Neuropathology in CWD-inoculated Tg[CerPrP] mice. All tissues are from CWD-inoculated, PLP-perfused mice stained with H\&E. Panels at left (A and $\mathbf{C}$ ) are tissues from a terminal i.v. inoculated Tg[CerPrP] mouse sacrificed at 201 dpi. Panels at right (B and D) are tissues obtained from a sham i.v. inoculated $\mathrm{Tg}[\mathrm{CerPrP}]$ mouse sacrificed at 201 dpi. A: Loss of neuronal cell bodies within the granular and Purkinje cell layers of the cerebellum, raggedy rarefaction of the neuropil, and the accumulation of eosinophilic plaques (outlined by arrows). C: Similar loss of neuronal cell bodies within the hippocampus, as well as rarefaction of the neuropil and eosinophilic plaques (outlined by arrows). In contrast, lack of neuropathological changes in sham-inoculated negative controls (B and $\mathbf{D})$. Scale bars: $50 \mu \mathrm{m}(\mathbf{A}) ; 40 \mu \mathrm{m}(\mathbf{B}) ; 75 \mu \mathrm{m}(\mathbf{C}$ and $\mathbf{D})$

phoid follicles, which is morphologically suggestive of either macrophages and/or dendritic cells (Figure 4D).

At subsequent time points PrPRES deposits were detected in the bone marrow, pancreatic islets, Peyer's patches, tongue, and salivary, adrenal, and pituitary

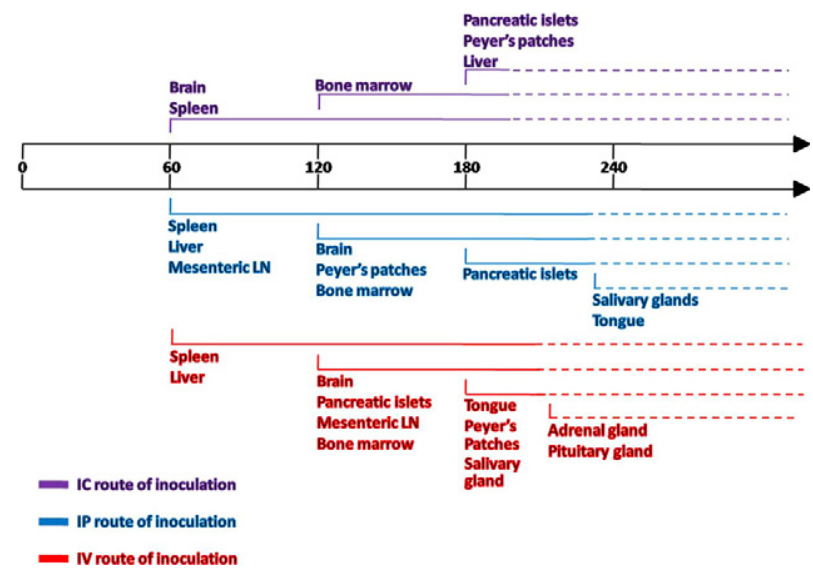

Figure 3. Longitudinal CWD $\mathrm{PrP}^{\mathrm{RES}}$ detection in Tg[CerPrP] mice after i.c., i.p., or i.v. inoculation. For each of the three routes of inoculation (green, i.c.; blue, i.p.; red, i.v.), tissues are listed by earliest sacrifice time point $(60,120$, 180 , and $240 \mathrm{dpi}$ ) at which $\mathrm{PrP}^{\mathrm{RES}}$ was detected by IHC. For each time point and each route, only those tissues in which the identification of $\mathrm{PrP}^{\mathrm{RES}}$ represented a new appearance are listed. The transition from solid to dashed line represents the approximate onset of terminal clinical disease. Tissues listed at the last time point represent IHC findings in terminal animals. LN, lymph nodes. glands. In the bone marrow, PrPRES deposits were finely granular to coarsely clumped and localized to a small number of nucleated cells (Figure 4E), which were interpreted to be of myeloid origin (nonerythroid/nonlymphoid). In the pancreas, PrPRES was limited to the cytoplasm of the islets of Langerhans (Figure 4F). In the tongue, $\operatorname{PrP}^{R E S}$ was detected in two microanatomic locations: within the cells of the taste bud and cells of lingual glands (Figure 4, G and $\mathrm{H}$ ). Within the lingual glands of the tongue, $\operatorname{PrP}^{R E S}$ accumulations were limited to the serous glands (Figure $4 \mathrm{H}$ ) with mucus glands lacking detectable PrPRES (data not shown).

In the salivary glands, PrPRES was detected in the serous epithelial cells of the submandibular salivary gland (Figure 4I). Within the adrenal gland, PrPRES was observed in the glandular cells of the adrenal medulla. Within one of two terminal i.v. inoculated mice, PrPRES deposits were seen in the pituitary gland, within cells of the neurohypophysis. PrPRES was not detected at any time point in any tissues from the following systems: musculoskeletal, reproductive, peripheral nervous, respiratory, or cardiovascular. Moreover, PrPRES was not identified in any of the tissues obtained from the sham-inoculated $\mathrm{Tg}[\mathrm{CerPrP}]$ mice.

\section{Successful Transmission of CWD to Orally Inoculated Tg[CerPrP] Mice}

In the initial p.o. inoculation study (above), none of the inoculated Tg[CerPrP] mice developed neurological disease (>700 dpi) or accumulated PrPRES in either brain or spleen (data not shown). To determine the role of inoculum dose in oral susceptibility, we inoculated a second group ( $n=5$ ) of Tg[CerPrP] mice with undiluted CWDpositive or CWD-negative brain. Three of the five CWDinoculated mice developed progressive and terminal neurological disease characterized by ataxia and mental obtundation, at 323, 350, and $378 \mathrm{dpi}$, and accumulated $\mathrm{PrP}^{\mathrm{RES}}$ in nervous and non-nervous tissues. The largest and most numerous immunoreactive aggregates were detected in the caudal aspects of the brain (obex, brainstem, and cerebellum) with decreasing amounts in the mid- and forebrain regions, including the hippocampus and hypothalamus. (Figure 5, A and B) with rare PrPRES detected in the neocortex. In the non-CNS tissues from these three mice, PrPRES was detected in the spleen (three of three), Peyer's patches (three of three), mesenteric lymph nodes (three of three), and pancreatic islets (two of three) (Figure 5C). PrPRES was not detected in the remainder of the peripheral tissues evaluated, including all remaining tissues from the gastrointestinal, urogenital, endocrine, and musculoskeletal systems. None of the sham-inoculated animals developed clinical disease nor did tissues from these mice contain PrPRES immunoreactivity. Thus, a 100\% fold increment in CWD brain homogenate dosage produced infection and disease by the oral route. 

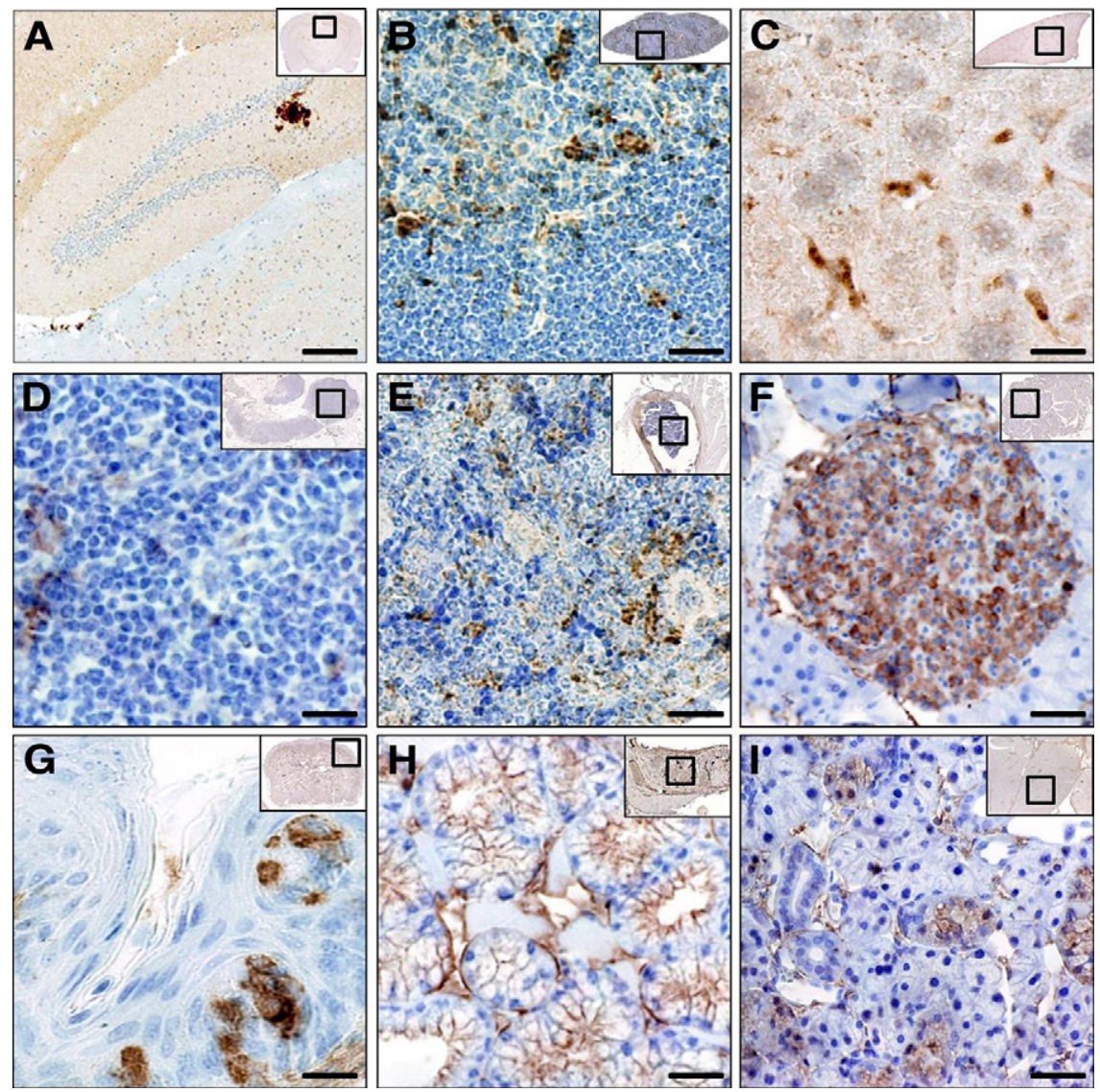

Figure 4. CWD $\operatorname{PrP}^{R E S}$ in tissues of i.c., i.p., and i.v. inoculated $\mathrm{Tg}[\mathrm{CerPrP}]$ mice. All tissues were obtained from PLP-perfused, CWD-inoculated mice and were immunostained using the IHC protocol detailed in Materials and Methods. A $\operatorname{PrP}^{\mathrm{RES}}$ (brown) in the hippocampus (in the hilus fasciae dentatae) at $60 \mathrm{dpi}$. B: $\operatorname{PrP}^{\mathrm{RES}}$ in the spleen, most notably within large cells of the marginal zone probably representing macrophages and/or dendritic cells at $60 \mathrm{dpi}$. C: Presence of $\mathrm{PrP}^{\mathrm{RES}}$ in the sinusoidal lining cells of the liver (probable Kupffer cells) at 120 dpi. D $\mathrm{PrP}^{\mathrm{RES}}$ within the mesenteric lymph node, most notably in large cells probably representing macrophages and/or dendritic cells at $180 \mathrm{dpi}$. E $\mathrm{PrP}^{\mathrm{RES}}$ in the bone marrow at 193 dpi. F: PrP ${ }^{\mathrm{RES}}$ in islet cells of the pancreas at 193 dpi. G: $\operatorname{PrP}^{R E S}$ in the cells of a lingual taste bud. $\mathbf{H}$ : $\operatorname{PrP}^{\mathrm{RES}}$ in cells of the mucus lingual glands. I: $\operatorname{PrP}^{\mathrm{RES}}$ in serous cells of the submandibular salivary gland at 233 dpi. Scale bars: $200 \mu \mathrm{m}(\mathbf{A}) ; 50 \mu \mathrm{m}(\mathbf{B}) ; 10$ $\mu \mathrm{m}(\mathbf{C}) ; 60 \mu \mathrm{m}(\mathbf{D}) ; 25 \mu \mathrm{m}(\mathbf{E}$ and $\mathbf{F}) ; 25 \mu \mathrm{m}(\mathbf{G})$ $60 \mu \mathrm{m}(\mathbf{H}) ; 25 \mu \mathrm{m}(\mathbf{I})$.

\section{Horizontal Transmission of CWD to Contact-Exposed Sentinel Tg[CerPrP] Mice}

To evaluate for the possibility of horizontal CWD transmission in $\mathrm{Tg}[\mathrm{CerPrP}]$ mice, one naive Tg[CerPrP] mouse was housed as a cohabitant with two CWD-inoculated mice. At each of the predetermined sacrifice time points (60, 120, 180, and 240 dpi), two CWD-inoculated mice and one sham-inoculated mouse were euthanized and necropsied. Thus, at the completion of each of these sacrifices, one of the five cohabitant mice assigned per inoculation group was left alone in the cage, resulting in sentinel mice that were exposed to the CWD-inoculated mice for either $60,120,180$, or 240 days or until terminal disease developed in inoculated cage-mates (171 to 233 days).
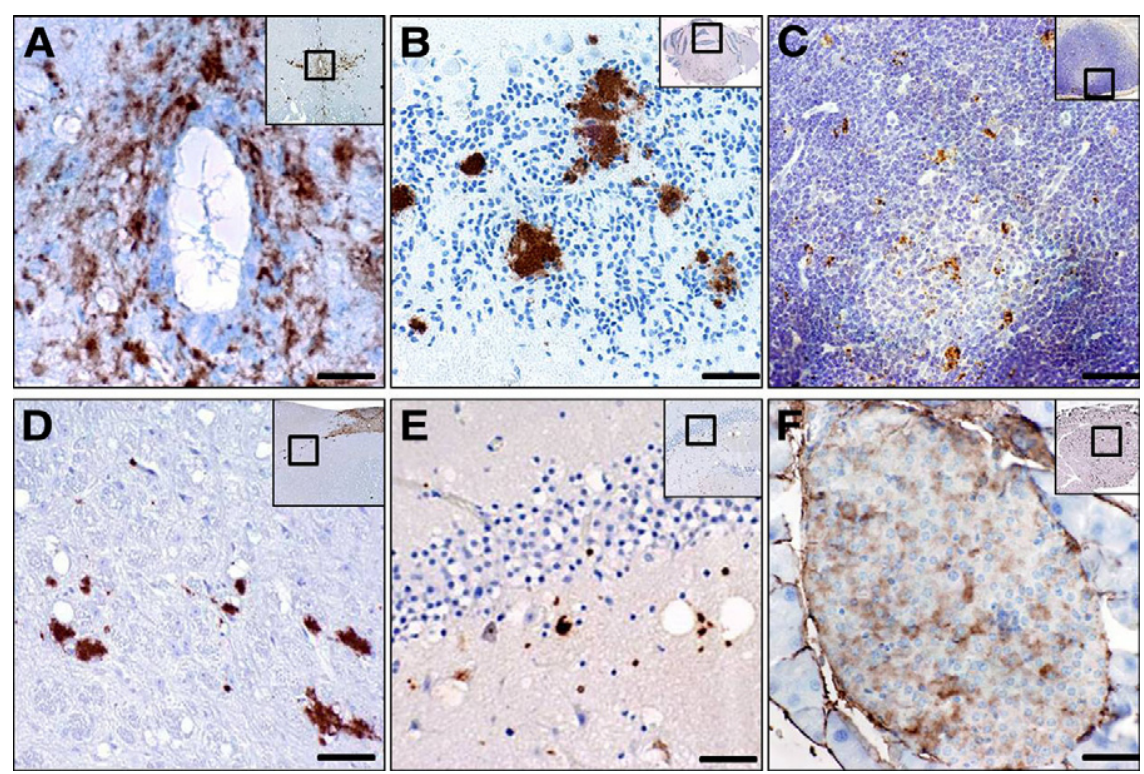

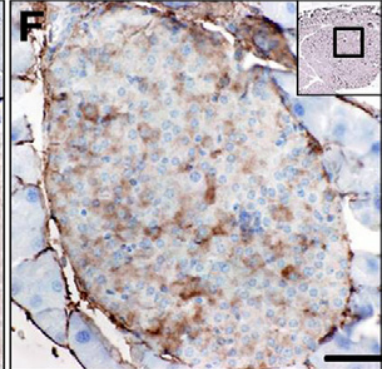

Figure 5. CWD $\mathrm{PrP}^{\mathrm{RES}}$ in tissues of p.o. inoculated and horizontally infected $\mathrm{Tg}[\mathrm{CerPrP}]$ mice. All tissues were obtained from either a terminally ill, PLP-perfused, p.o. inoculated mouse sacrificed at $350 \mathrm{dpi}(\mathbf{A}-\mathbf{C})$ or from a terminally ill, PLP-perfused, noninoculated mouse that $\mathrm{CO}^{-}$ habitated with an i.c. inoculated mice that was sacrificed because of terminal neurological disease (D-F). All tissues were immunostained using the IHC protocol detailed in Materials and Methods. Each panel demonstrates PrP ${ }^{\mathrm{RES}}$ immunoreactivity (brown) in selected tissues. A: $\mathrm{PrP}^{\mathrm{RES}}$ in the cervical spinal cord, including heavy deposition surrounding the central canal. B: PrPRES in the granular layer of the cerebellum C: $\mathrm{PrP}^{\mathrm{RES}}$ in the cells of the Peyer's patch which, based on size and cytomorphologic characteristics, are probably macrophages and/or dendritic cells D: $\operatorname{PrP} P^{R E S}$ in the brainstem. E: $\operatorname{PrP}^{\mathrm{RES}}$ in the hippocampus (hilus fasciae dentatae). F: $\operatorname{PrP}^{\mathrm{RES}}$ in the pancreatic islets. Scale bars: $25 \mu \mathrm{m}(\mathbf{A}) ; 75 \mu \mathrm{m}(\mathbf{B})$; $200 \mu \mathrm{m}(\mathbf{C}) ; 25 \mu \mathrm{m}(\mathbf{D}) ; 60 \mu \mathrm{m}(\mathbf{E}) ; 50 \mu \mathrm{m}(\mathbf{F})$. 

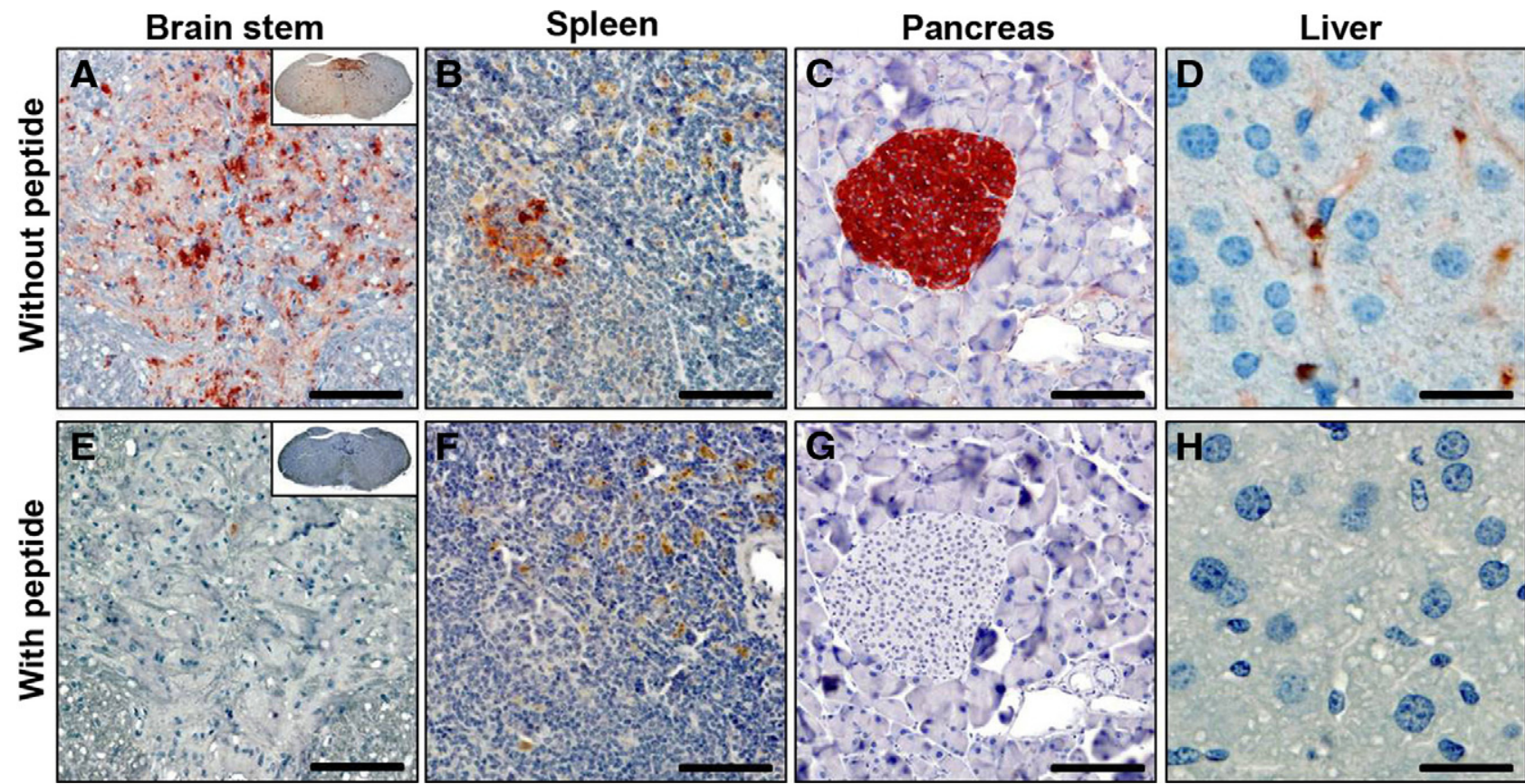

Figure 6. Blocking of $\mathrm{PrP}^{\mathrm{RES}}$ immunoreactivity by target peptide before incubation. All tissues were obtained from a terminally ill, PLP-perfused, i.p. inoculated $\mathrm{Tg}[\mathrm{CerPrP}]$ mouse sacrificed at $233 \mathrm{dpi}$. Tissues were immunostained using an IHC protocol incorporating the BAR-224 monoclonal antibody, amplification using TSA reagents and a peptide blocking step. Top row (no blocking): PrP ${ }^{\text {RES }}$ immunoreactivity (red) in (A) brainstem neuropil, (B) splenic nucleated cells, (C) pancreatic islet epithelial cells, and (D) hepatic Kupffer cells. Bottom row (blocking): Pre-application incubation of the primary antibody with its eliciting peptide results in complete to near-complete abrogation of $\operatorname{PrP}^{\mathrm{RES}}$ immunoreactivity in matched tissue sections $(\mathbf{E}-\mathbf{H})$. Scale bars: $100 \mu \mathrm{m}(\mathbf{A}$ and $\mathbf{E}) ; 100 \mu \mathrm{m}(\mathbf{B}$ and $\mathbf{F})$; $80 \mu \mathrm{m}(\mathbf{C}$ and $\mathbf{G}) ; 27.5 \mu \mathrm{m}(\mathbf{D}$ and $\mathbf{H})$

After the sacrifice of their inoculated cage-mates, the cohabitant mice were allowed to live out the remainder of the study (600 dpi) or until the onset of either i) clinical neurological disease or ii) clinical signs of any other disease which necessitated humane euthanasia. Of these 20 sentinel mice, 3 demonstrated clinical neurological dysfunction and had immunohistochemically detectable PrP ${ }^{R E S}$ within the brain, although only 15 were observed over a long enough observation period (600 dpi) to allow for detection of infection and disease. The first affected mouse was housed with two i.c. inoculated mice for 193 days and was sacrificed at 543 days postexposure. The second affected mouse was housed with two i.p. inoculated mice for 233 days and was sacrificed at 562 days postexposure. The third affected mouse was housed with two i.v. inoculated mice for 201 days and was sacrificed at 551 days postexposure. These three mice lived for 350, 329, and 350 days, respectively, after the sacrifice of their inoculated cage-mates. Thus, of the 15 mice exposed to infected cage-mates that survived to the end of the study (600 dpi), 3 developed a TSE.

\section{Lesions and PrP ${ }^{R E S}$ in Horizontally Infected Tg[CerPrP] Mice}

Neuropathological findings in the affected Tg[CerPrP] mice were identical to those seen in the i.c., i.p., and i.v. inoculated mice. PrPRES distribution in the brains of horizontally infected mice was similar to that in the high-dose p.o. inoculated mice, with heavy $\operatorname{PrP}^{\mathrm{RES}}$ deposits in the obex, brainstem, and cerebellum (Figure 5, D-E) and smaller, less frequent PrPRES deposits in the hippocampus, hypothalamus, and neocortex. PrPRES was also detected in the spleen, Peyer's patches, and pancreatic islets (Figure 5F). PrPRES was not detected in the remainder of the peripheral tissues evaluated, including all remaining tissues from the gastrointestinal, urogenital, endocrine, and musculoskeletal systems.

\section{Abrogation of PrP ${ }^{R E S}$ Immunoreactivity Using Peptide Blocking}

To confirm the specificity of the PrPRES $\mathrm{HC}$ detection protocols, tissues previously identified as $\operatorname{PrPRES}^{\mathrm{RES}}$-positive were subjected to an $\mathrm{IHC}$ protocol, which incorporated a preincubation of the primary, anti-prion antibody with its eliciting peptide. In these experiments, there was nearcomplete to complete abrogation of PrPRES immunoreactivity when such a peptide, preincubation step was incorporated (Figure 6, A-H).

\section{Discussion}

Although the effectiveness of peripheral inoculation in prion diseases seems to rely, in part, on the expression of $\mathrm{PrP}^{\mathrm{C}}$ in peripheral (non-CNS) tissues, there are few published data regarding the systemic expression patterns of $\mathrm{PrP}^{\mathrm{C}}$ in the tissues of transgenic mice expressing $\mathrm{PrP}^{\mathrm{C}}$ of alternate species. ${ }^{22-25}$ In the initial characterization of the $1536 \mathrm{Tg}[\mathrm{CerPrP}]$ strain used in these studies, cervid PrP was detected only in the brain by dot and Western blot- 
ting using monoclonal antibody $6 \mathrm{H} 4 .{ }^{6}$ To expand on the initial characterization of $1536 \mathrm{Tg}$ [CerPrP] mice we used PLP fixation and the polyclonal anti-prion antibody R505.5 to identify $\operatorname{PrP}^{\mathrm{C}}$ expression in cell populations in the nervous, lymphoid, endocrine, reproductive, gastrointestinal, and hematopoietic systems (Table 1): a pattern of expression similar to that reported for expression of native species $\mathrm{PrP}^{\mathrm{C}}$ in rodents and cervids. ${ }^{26-30}$ Morphologically, the pattern of $\mathrm{PrPC}^{\mathrm{C}}$ immunoreactivity varied widely between individual cell and tissue types from finely granular to punctate to aggregate in nature. Such a pattern of $\mathrm{PrPC}^{\mathrm{C}}$ immunoreactivity is similar to that described in other $\mathrm{PrPC}^{\mathrm{C}}$ mapping studies in the adult mouse $\mathrm{e}^{28,31}$ and may be reflective of the varied, and often high, level of protein expressed in the immunopositive cells. In certain cell types (ie, splenic lymphocytes and brain neurons) the high levels of protein might saturate the detection system, resulting in aggregation of the chromogen. Based on the lack of corresponding immunoreactivity in the $\mathrm{Pr}^{\mathrm{O} / 0}$ mice, we are confident that the protocol used to detect $\mathrm{PrP}^{\mathrm{C}}$ produced accurate and specific results. Finally, these findings provide the first evidence suggesting that the cosTet vector system is capable of manifesting peripheral expression of a prion protein of a heterologous species and complement recent work confirming this vector system as being capable of manifesting widespread prion protein expression in the mouse. ${ }^{5-11,13,14,32-35}$

In these studies, we used the combination of clinical disease and the immunohistochemical detection of PrPRES to document successful CWD infection in the inoculated $\mathrm{Tg}[\mathrm{CerPrP}]$ mice. The use of such an approach is justified by previously published prion pathogenesis and $\mathrm{PrP}^{\mathrm{RES}}$ mapping studies, including those evaluating longitudinal patterns of CWD prion accumulation in native cervid species. ${ }^{17,21,36}$ Although we did not include concurrent immunoblot analysis of all tissue samples, we believe the sensitivity of the TSA-based immunohistochemical detection techniques used provided sensitivity that was more than equivalent to tissue homogenate Western blotting. Moreover, we believe that the results from the peptide blocking and $\mathrm{PrP}^{\mathrm{O} / 0}$ studies confirm the specificity of the PrP ${ }^{R E S}$ longitudinal mapping results.

We demonstrate the susceptibility of $\mathrm{Tg}[\mathrm{CerPrP}]$ mice to $C W D$ after the i.c., i.v., i.p., and p.o. routes, expanding on previously published work. ${ }^{6}$ Although this is the first report documenting the susceptibility of $1536 \mathrm{Tg}$ [CerPrP] mice to infection with CWD after i.p., i.v., and p.o. routes of inoculation, this is not the first report documenting oral susceptibility of cervidized mice to CWD. Trifilo et al ${ }^{9}$ demonstrated that oral inoculation of two other lines of cerPrP transgenic mice produced clinical TSE in both lines at $370 \pm 26$ and $381 \pm 55 \mathrm{dpi}$, respectively, ${ }^{9}$ which is similar to our findings of $350 \pm 27 \mathrm{dpi}$. The failure of the initial group of orally inoculated mice to demonstrate susceptibility to CWD is probably the result of an insufficient inoculum dose, a point that is emphasized by both the successful inoculation of three of five mice fed a whole-brain inoculum and the successful p.o. inoculation study cited above, in which a more concentrated (5\%) brain homogenate proved successful. ${ }^{9}$

Through serial sacrifice, we were able to demonstrate longitudinal patterns of PrPRES tissue tropism suggestive of a three-phase pathogenesis: i) an early lymphoreticular system-associated phase characterized by the accumulation of PrPRES in lymphoid compartments (spleen and/or lymph node), ii) a neuroinvasive phase, whereby PrPRES became detectable in the CNS, and iii) the terminal accumulation of $\operatorname{PrP}^{R E S}$ within peripheral tissues. The first two phases are most evident in the temporal patterns of $\operatorname{PrP}^{R E S}$ accumulation in the i.v. and i.p. inoculated mice in which the early lymphoreticular system accumulation phase was demonstrated. In these tissues, PrPRES was observed within likely follicular dendritic cells, cells that have been shown to be important enablers of prion disease propagation and neuroinvasion. . $1,37-43$

Detection of splenic PrPRES at a time point (60 dpi) preceding PrPRES detection in the brain (120 dpi) suggests that splenic-mediated neuroinvasion plays a role in $\mathrm{Tg}[\mathrm{CerPrP}]$ mice, as has been theorized for scrapie prion transit via nerve fibers associated with follicular dendritic cell-rich splenic germinal centers as conduits to the thoracic spinal cord. ${ }^{44,45}$ Although splenic-mediated neuroinvasion remains the most likely possibility, we cannot exclude the possibility of hematogenous neuroinvasion, a phenomenon that, although little investigated, finds support in the literature and in the detection of infectious prions in blood. ${ }^{46-52}$

The third phase of CWD pathogenesis in Tg[CerPrP] mice was marked by the accumulation of PrPRES in peripheral tissues (denoted terminal PrPRES dissemination). In this phase, PrPRES deposits were detected in the bone marrow, pancreatic islets, Peyer's patches, mesenteric lymph nodes, adrenal gland, pituitary gland, tongue, and salivary gland. Such a pattern is typical of the progressive vagal and sympathetic nervous system-mediated, centrifugal dissemination of prions from the brain in the later to terminal stages of prion disease as described in previous mouse, sheep, and hamster models. $24,53-56$

In the successfully infected $\mathrm{Tg}[\mathrm{CerPrP}]$ mice, there were exceptions to the proposed two- to three-step pathogenesis, ie, instances in which PrPRES was identified in peripheral tissues either before or simultaneous with its identification in the CNS. Such cases included the identification of PrPRES in the spleen or liver of i.v., i.p., and i.c. inoculated mice sacrificed at $60 \mathrm{dpi}$ or in the pancreatic islets of i.v. inoculated animals sacrificed at $120 \mathrm{dpi}$. These findings support the presence of a transient, postinoculation period of hematogenous prion trafficking, which results in the delivery of inoculum-origin prions to peripheral tissues. Such a phenomenon, described as a spillover "prionemia," has been reported after the i.p. or i.c. inoculation of scrapie or CreutzfeldtJakob disease prions, such that infectious prions accumulate in peripheral tissues (bone marrow, adrenal gland, salivary gland, and spleen), either before or coincident with the identification of prions in the brain and that infectious prions can be detected in the blood immediately after i.p. and i.c. inoculation. ${ }^{43,57-59}$ 
The more novel detection of PrPRES in the salivary glands, bone marrow, neuroendocrine system, and neurosensory cells of the tongue confirms the utility of $\mathrm{Tg}[$ CerPrP] mice as effective surrogates for CWD infection. Moreover, serial sacrifice and longitudinal PrPRES accumulation data offer insights into the manner by which prions traffic to these tissues. In the salivary glands, we identified PrPRES only after it was identified in the CNS, which suggests that centrifugal spread along neural pathways is responsible for prion delivery. The salivary glands secrete in response to stimuli provided by the autonomic nervous system, including fibers of both the parasympathetic and sympathetic systems via the medulla oblongata and lateral hypothalamus. ${ }^{60,61}$ Although we did not track the accumulation of prions along specific peripheral and cranial nerve tracts, in our terminal i.v. and i.p. inoculated mice we did identify significant deposits of PrPRES within the pons and the ventromedial hypothalamus, which have been described as the salivary centers of the brain. ${ }^{61}$ Finally, the pattern of PrPRES deposition in the salivary glands, with $\operatorname{PrP}^{\mathrm{RES}}$ accumulations present on the surface of acinar epithelial cells, is similar to that reported in an IHC study published in scrapie-affected sheep ${ }^{62}$ and suggests that salivary secretion of prions may result from normal, physiological activity of glands during the process of saliva secretion. ${ }^{63}$

The demonstration of PrPRES in the bone marrow of $\mathrm{Tg}[\mathrm{Ce} P \mathrm{PrP}]$ mice, although novel in the CWD system, is consistent with our identification of $\mathrm{PrPC}^{\mathrm{C}}$ in this compartment and with published work in murine models of scrapie. ${ }^{43,64}$ Although the route by which PrPRES accumulated in the bone marrow is uncertain, the weight of the evidence suggests a pathway of hematogenous trafficking, as demonstrated by studies showing the feasibility of blood-borne transmission in several prion diseases (bovine spongiform encephalopathy, scrapie, CWD, and new variant Creutzfeldt-Jakob disease), as well as work detecting prions in the blood of preclinical, scrapie-infected hamsters, and CWD-infected deer. ${ }^{46-50}$ Identification of PrPRES in the endocrine system of cervidized mice has not been reported previously but resembles findings in orally inoculated and naturally infected mule deer, in which PrPRES was demonstrated in the adrenal medulla, islets of Langerhans, and pituitary of animals with latestage CWD. ${ }^{36,65}$ PrPRES has also been seen in the pancreas of goats and sheep with natural scrapie and in hamsters and mice with experimental scrapie. ${ }^{66-68} \mathrm{Be}-$ cause PrPRES was detectable in endocrine tissues only after its detection in the brain, centrifugal dissemination via the vagus nerve, splanchnic nerves, and fibers from the hypothalamus to the pancreatic islets, adrenal gland, and pars nervosa of the pituitary gland, respectively, is likely. ${ }^{69,70}$

The identification of PrPRES in the lingual taste buds and glands is intriguing. PrPRES has been reported previously in the tongues of hamsters i.c. inoculated with transmissible mink encephalopathy, in hamsters p.o. inoculated with scrapie, in transgenic mice p.o. inoculated with CWD, and in sheep with natural scrapie. ${ }^{9,71-73}$ Using $\mathrm{IHC}$ and confocal microscopy, Bessen and colleagues ${ }^{54}$ demonstrated that PrPRES accumulates within the nerve fibers, taste buds, and stratified squamous epithelium in the fungiform papillae as well as within nerve fascicles and skeletal muscle cells. Trifilo et $\mathrm{al}^{9}$ demonstrated PrPRES in occasional taste buds of p.o. inoculated cervidized transgenic mice. We found PrPRES in the tongue only late in disease (180 to $240 \mathrm{dpi}$ ), after its appearance in the brain, again suggesting centrifugal spread, probably via cranial nerve fibers (facial [VII] and trigeminal $[V]$ ), a pathway proven in hamsters inoculated with transmissible mink encephalopathy. ${ }^{71}$ In addition to taste buds, we identified PrPRES in the lingual glands, consistent with the findings of Trifilo et al, ${ }^{9}$ suggesting centrifugal dissemination via the hypoglossal nerve., ${ }^{9,74}$

In association with the direct CWD inoculation studies, we demonstrated, for the first time, the horizontal transmission of CWD prions in a rodent model system. Whereas lateral transmission is a prominent feature of CWD and scrapie, little published information exists in rodent models. ${ }^{1,75,76}$ Although questions remain regarding the nature of this transmission, based on the identical pattern of PrPRES accumulation seen in naturally and experimentally (p.o.) infected cervids orally infected mice in this study, we reason that the contact-exposed mice were infected by the oral route. ${ }^{17,21,65,77,78}$ The precedent for the horizontal transmission of pathogens between cohabitant cage-mates is provided by work detailing the horizontal spread of hantavirus and Helicobacter pylori between murine cage-mates. ${ }^{79,80}$ The vehicle responsible for the spread of prions between cage-mates is uncertain, but other studies in cervids and rodent model systems support the plausibility of biological fluids and excreta as transmission vehicles. ${ }^{48,81,82}$ Given the presence of PrPRES in the taste buds of inoculated Tg[CerPrP] mice, horizontal spread could be linked to the shedding of prion-infected cells into oronasal secretions. ${ }^{71}$ In addition to direct animal-to-animal contact or animal-to-excreta contact, coprophagy is also plausible, as evidenced by the transmission of CWD and scrapie by exposure of naive animals to a contaminated environment. ${ }^{82,83}$

In summary, cervidized transgenic mice substantially recapitulate the clinical, neuropathological, and PrPRES tropism, and transmission patterns reported in the native cervid species ${ }^{21,36,65,77,78,84}$ and studies in Tg[CerPrP] mice can provide additional insights into the trafficking, shedding, and lateral transmission of CWD prions.

\section{Acknowledgments}

We thank Jan Langeveld for his generous gift of anti-prion antibody R505.5. We thank Jeanette Hayes-Klug, Heather Bender, Kelly Anderson, Erin McNulty, and Kate Bruner for their excellent care and management of the Tg mice used in these studies. We thank Mark Zabel for his helpful comments on this work and for provision of the $\mathrm{PrP}^{\mathrm{O} / 0}$ mice.

\section{References}

1. Miller MW, Williams ES: Prion disease: horizontal prion transmission in mule deer. Nature 2003, 425:35-36 
2. Miller MW, Wild MA, Williams ES: Epidemiology of chronic wasting disease in captive Rocky Mountain elk. J Wildl Dis 1998, 34:532-538

3. Miller MW, Wild MA: Epidemiology of chronic wasting disease in captive white-tailed and mule deer. J Wildl Dis 2004, 40:320-327

4. Williams ES, Young S: Spongiform encephalopathies in Cervidae. Rev Sci Tech 1992, 11:551-567

5. Angers RC, Browning SR, Seward TS, Sigurdson CJ, Miller MW, Hoover EA, Telling GC: Prions in skeletal muscles of deer with chronic wasting disease. Science 2006, 311:1117

6. Browning SR, Mason GL, Seward T, Green M, Eliason GA, Mathiason C, Miller MW, Williams ES, Hoover E, Telling GC: Transmission of prions from mule deer and elk with chronic wasting disease to transgenic mice expressing cervid PrP. J Virol 2004, 78:13345-13350

7. Kong Q, Huang S, Zou W, Vanegas D, Wang M, Wu D, Yuan J, Zheng M, Bai H, Deng H, Chen K, Jenny AL, O'Rourke K, Belay ED, Schonberger LB, Petersen RB, Sy MS, Chen SG, Gambetti P: Chronic wasting disease of elk: transmissibility to humans examined by transgenic mouse models. J Neurosci 2005, 25:7944-7949

8. Tamgüney G, Giles K, Bouzamondo-Bernstein E, Bosque PJ, Miller MW, Safar J, DeArmond SJ, Prusiner SB: Transmission of elk and deer prions to transgenic mice. J Virol 2006, 80:9104-9114

9. Trifilo MJ, Ying G, Teng C, Oldstone MB: Chronic wasting disease of deer and elk in transgenic mice: oral transmission and pathobiology. Virology 2007, 365:136-143

10. LaFauci G, Carp RI, Meeker HC, Ye X, Kim JI, Natelli M, Cedeno M, Petersen RB, Kascsak R, Rubenstein R: Passage of chronic wasting disease prion into transgenic mice expressing Rocky Mountain elk (Cervus elaphus nelsoni) PrPC. J Gen Virol 2006, 87:3773-3780

11. Scott MR, Safar J, Telling G, Nguyen O, Groth D, Torchia M, Koehler R, Tremblay P, Walther D, Cohen FE, DeArmond SJ, Prusiner SB: Identification of a prion protein epitope modulating transmission of bovine spongiform encephalopathy prions to transgenic mice. Proc Natl Acad Sci USA 1997, 94:14279-14284

12. Telling GC: Prion protein genes and prion diseases: studies in transgenic mice. Neuropathol Appl Neurobiol 2000, 26:209-220

13. Telling GC, Scott M, Hsiao KK, Foster D, Yang SL, Torchia M, Sidle KC, Collinge J, DeArmond SJ, Prusiner SB: Transmission of Creutzfeldt-Jakob disease from humans to transgenic mice expressing chimeric human-mouse prion protein. Proc Natl Acad Sci USA 1994, 91:9936-9940

14. Telling GC, Scott M, Mastrianni J, Gabizon R, Torchia M, Cohen FE, DeArmond SJ, Prusiner SB: Prion propagation in mice expressing human and chimeric PrP transgenes implicates the interaction of cellular PrP with another protein. Cell 1995, 83:79-90

15. Scott MR, Kohler R, Foster D, Prusiner SB: Chimeric prion protein expression in cultured cells and transgenic mice. Protein Sci 1992, 1:986-997

16. Baron T: Mouse models of prion disease transmission. Trends Mol Med 2002, 8:495-500

17. Sigurdson CJ, Williams ES, Miller MW, Spraker TR, O'Rourke KI, Hoover EA: Oral transmission and early lymphoid tropism of chronic wasting disease PrPres in mule deer fawns (Odocoileus hemionus). J Gen Virol 1999, 80(Pt 10):2757-2764

18. Carlson GA, Kingsbury DT, Goodman PA, Coleman S, Marshall ST, DeArmond S, Westaway D, Prusiner SB: Linkage of prion protein and scrapie incubation time genes. Cell 1986, 46:503-511

19. Petrusz P, Bullock G. Edited by H. Hedrich: The laboratory mouse. Elsevier Academic Press 2004

20. Garssen GJ, Van Keulen LJ, Farquhar CF, Smits MA, Jacobs JG, Bossers A, Meloen RH, Langeveld JP: Applicability of three anti-PrP peptide sera including staining of tonsils and brainstem of sheep with scrapie. Microsc Res Tech 2000, 50:32-39

21. Sigurdson CJ, Barillas-Mury C, Miller MW, Oesch B, van Keulen LJ, Langeveld JP, Hoover EA: PrP(CWD) lymphoid cell targets in early and advanced chronic wasting disease of mule deer. J Gen Virol 2002, 83:2617-2628

22. Brandner S, Isenmann S, Raeber A, Fischer M, Sailer A, Kobayashi Y, Marino S, Weissmann C, Aguzzi A: Normal host prion protein necessary for scrapie-induced neurotoxicity. Nature 1996, 379:339-343

23. Glatzel M, Aguzzi $A$ : $\operatorname{Pr} P(C)$ expression in the peripheral nervous system is a determinant of prion neuroinvasion. J Gen Virol 2000 81:2813-2821

24. Blättler T, Brandner S, Raeber AJ, Klein MA, Voigtlander T, Weissmann
C, Aguzzi A: PrP-expressing tissue required for transfer of scrapie infectivity from spleen to brain. Nature 1997, 389:69-73

25. Le Pichon CE, Firestein S: Expression and localization of the prion protein $\operatorname{Pr} P(C)$ in the olfactory system of the mouse. J Comp Neurol 2008, 508:487-499

26. Burthem J, Urban B, Pain A, Roberts DJ: The normal cellular prion protein is strongly expressed by myeloid dendritic cells. Blood 2001 98:3733-3738

27. Liu T, Li R, Wong BS, Liu D, Pan T, Petersen RB, Gambetti P, Sy MS Normal cellular prion protein is preferentially expressed on subpopulations of murine hemopoietic cells. J Immunol 2001, 166:3733-3742

28. Ford MJ, Burton LJ, Morris RJ, Hall SM: Selective expression of prion protein in peripheral tissues of the adult mouse. Neuroscience 2002, 113:177-192

29. Mathiason C, Foos T, Eliason GA, Sigurdson CJ, Miller M, Lewis-Weis L, Fischer J, Hoover E: Cervid PrPc Quantitation and Tissue Mapping. Presented at the College of Veterinary Medicine and Biomedical Sciences Research Day (Microbiology, Immunology, and Pathology). 2004 January 29. Fort Collins, CO

30. Zhang CC, Steele AD, Lindquist S, Lodish HF: Prion protein is expressed on long-term repopulating hematopoietic stem cells and is important for their self-renewal. Proc Natl Acad Sci USA 2006, 103:2184-2189

31. Brown KL, Ritchie DL, McBride PA, Bruce ME: Detection of PrP in extraneural tissues. Microsc Res Tech 2000, 50:40-45

32. Asante EA, Linehan JM, Desbruslais M, Joiner S, Gowland I, Wood AL, Welch J, Hill AF, Lloyd SE, Wadsworth JD, Collinge J: BSE prions propagate as either variant CJD-like or sporadic CJD-like prion strains in transgenic mice expressing human prion protein. EMBO $J$ 2002, 21:6358-6366

33. Prusiner SB, Scott M, Foster D, Pan KM, Groth D, Mirenda C, Torchia M, Yang SL, Serban D, Carlson GA, Hoppe PC, Westaway D, DeArmond SJ: Transgenetic studies implicate interactions between homologous PrP isoforms in scrapie prion replication. Cell 1990, 63:673-686

34. Scott M, Foster D, Mirenda C, Serban D, Coufal F, Walchli M, Torchia M, Groth D, Carlson G, DeArmond SJ, Westaway D, Prusiner SB: Transgenic mice expressing hamster prion protein produce species-specific scrapie infectivity and amyloid plaques. Cell 1989, 59:847-857

35. Tremblay P, Bouzamondo-Bernstein E, Heinrich C, Prusiner SB, DeArmond SJ: Developmental expression of PrP in the post-implantation embryo. Brain Res 2007, 1139:60-67

36. Sigurdson CJ, Spraker TR, Miller MW, Oesch B, Hoover EA $\operatorname{PrP}(C W D)$ in the myenteric plexus, vagosympathetic trunk and endocrine glands of deer with chronic wasting disease. J Gen Virol 2001, 82:2327-2334

37. Muramoto T, Kitamoto T, Tateishi J, Goto I: Accumulation of abnormal prion protein in mice infected with Creutzfeldt-Jakob disease via intraperitoneal route: a sequential study. Am J Pathol 1993, 143:1470-1479

38. Mabbott NA, Mackay F, Minns F, Bruce ME: Temporary inactivation of follicular dendritic cells delays neuroinvasion of scrapie. Nat Med 2000, 6:719-720

39. Mabbott NA, MacPherson GG: Prions and their lethal journey to the brain. Nat Rev Microbiol 2006, 4:201-211

40. Mabbott NA, Young J, McConnell I, Bruce ME: Follicular dendritic cell dedifferentiation by treatment with an inhibitor of the lymphotoxin pathway dramatically reduces scrapie susceptibility. J Virol 2003, 77:6845-6854

41. Mohan J, Bruce ME, Mabbott NA: Follicular dendritic cell dedifferentiation reduces scrapie susceptibility following inoculation via the skin. Immunology 2005, 114:225-234

42. Huang FP, Farquhar CF, Mabbott NA, Bruce ME, MacPherson GG Migrating intestinal dendritic cells transport PrPSc from the gut. J Gen Virol 2002, 83:267-271

43. Kimberlin $\mathrm{RH}$, Walker $\mathrm{CA}$ : The role of the spleen in the neuroinvasion of scrapie in mice. Virus Res 1989, 12:201-211

44. Prinz M, Heikenwalder M, Junt T, Schwarz P, Glatzel M, Heppner FL, Fu YX, Lipp M, Aguzzi A: Positioning of follicular dendritic cells within the spleen controls prion neuroinvasion. Nature 2003, 425:957-962

45. Glatzel M, Heppner FL, Albers KM, Aguzzi A: Sympathetic innervation of lymphoreticular organs is rate limiting for prion neuroinvasion. Neuron 2001, 31:25-34

46. Hunter N, Foster J, Chong A, McCutcheon S, Parnham D, Eaton S, MacKenzie C. Houston F: Transmission of prion diseases by blood transfusion. J Gen Virol 2002, 83:2897-2905 
47. Llewelyn CA, Hewitt PE, Knight RS, Amar K, Cousens S, Mackenzie J, Will RG: Possible transmission of variant Creutzfeldt-Jakob disease by blood transfusion. Lancet 2004, 363:417-421

48. Mathiason CK, Powers JG, Dahmes SJ, Osborn DA, Miller KV, Warren RJ, Mason GL, Hays SA, Hayes-Klug J, Seelig DM, Wild MA, Wolfe LL, Spraker TR, Miller MW, Sigurdson CJ, Telling GC, Hoover EA: Infectious prions in the saliva and blood of deer with chronic wasting disease. Science 2006, 314:133-136

49. Peden AH, Head MW, Ritchie DL, Bell JE, Ironside JW: Preclinical VCJD after blood transfusion in a PRNP codon 129 heterozygous patient. Lancet 2004, 364:527-529

50. Saá P, Castilla J, Soto C: Presymptomatic detection of prions in blood. Science 2006, 313:92-94

51. Viegas P, Chaverot N, Enslen H, Perriere N, Couraud PO, Cazaubon $\mathrm{S}$ : Junctional expression of the prion protein PrPC by brain endothelial cells: a role in trans-endothelial migration of human monocytes. J Cell Sci 2006, 119:4634-4643

52. Banks WA, Niehoff ML, Adessi C, Soto C: Passage of murine scrapie prion protein across the mouse vascular blood-brain barrier. Biochem Biophys Res Commun 2004, 318:125-130

53. Beekes M, McBride PA: The spread of prions through the body in naturally acquired transmissible spongiform encephalopathies. FEBS J 2007, 274:588-605

54. Mulcahy ER, Bartz JC, Kincaid AE, Bessen RA: Prion infection of skeletal muscle cells and papillae in the tongue. J Virol 2004 78:6792-6798

55. Borchelt DR, Koliatsos VE, Guarnieri M, Pardo CA, Sisodia SS, Price DL: Rapid anterograde axonal transport of the cellular prion glycoprotein in the peripheral and central nervous systems. J Biol Chem 1994, 269:14711-14714

56. Moya KL, Hassig R, Creminon C, Laffont I, Di Giamberardino L: Enhanced detection and retrograde axonal transport of PrPc in peripheral nerve. J Neurochem 2004, 88:155-160

57. Bruce ME: Agent replication dynamics in a long incubation period model of mouse scrapie. J Gen Virol 1985, 66(Pt 12):2517-2522

58. Field EJ, Caspary EA, and Joyce G: Scrapie agent in blood. Vet Rec 1968, 83:109-110

59. Millson GC, Kimberlin RH, Manning EJ, Collis SC: Early distribution of radioactive liposomes and scrapie infectivity in mouse tissues following administration by different routes. Vet Microbiol 1979, 5:89-99

60. Zoukhri D, Kublin CL: Impaired neurotransmitter release from lacrimal and salivary gland nerves of a murine model of Sjögren's syndrome. Invest Ophthalmol Vis Sci 2001, 42:925-932

61. Proctor GB, Carpenter GH: Regulation of salivary gland function by autonomic nerves. Auton Neurosci 2007, 133:3-18

62. Vascellari M, Nonno R, Mutinelli F, Bigolaro M, Di Bari MA, Melchiotti E, Marcon S, D'Agostino C, Vaccari G, Conte M, De Grossi L, Rosone F, Giordani F, Agrimi U: PrPSc in salivary glands of scrapie-affected sheep. J Virol 2007, 81:4872-4876

63. McManaman JL, Reyland ME, Thrower EC: Secretion and fluid transport mechanisms in the mammary gland: comparisons with the exocrine pancreas and the salivary gland. J Mammary Gland Biol Neoplasia 2006, 11:249-268

64. Eklund CM, Kennedy RC, Hadlow WJ: Pathogenesis of scrapie virus infection in the mouse. J Infect Dis 1967, 117:15-22

65. Fox KA, Jewell JE, Williams ES, Miller MW: Patterns of PrPCWD accumulation during the course of chronic wasting disease infection in orally inoculated mule deer (Odocoileus hemionus). J Gen Virol 2006, 87:3451-3461
66. Ye X, Carp Rl, Yu Y, Kozielski R, Kozlowski P: Hyperplasia and hypertrophy of $B$ cells in the islets of Langerhans in hamsters infected with the $139 \mathrm{H}$ strain of scrapie. J Comp Pathol 1994, 110:169-183

67. Pattison $I H$, Millson GC: Further observations on the experimental production of scrapie in goats and sheep. J Comp Pathol 1960, 70:182-193

68. McBride PA, Eikelenboom P, Kraal G, Fraser H, Bruce ME: PrP protein is associated with follicular dendritic cells of spleens and lymph nodes in uninfected and scrapie-infected mice. J Pathol 1992, 168:413-418

69. Loewy AD, Franklin MF, Haxhiu MA: CNS monoamine cell groups projecting to pancreatic vagal motor neurons: a transneuronal labeling study using pseudorabies virus. Brain Res 1994, 638:248-260

70. Kesse WK, Parker TL, Coupland RE: The innervation of the adrenal gland. I. The source of pre- and postganglionic nerve fibres to the rat adrenal gland. J Anat 1988, 157:33-41

71. DeJoia C, Moreaux B, O'Connell K, Bessen RA: Prion infection of oral and nasal mucosa. J Virol 2006, 80:4546-4556

72. Thomzig A, Kratzel C, Lenz G, Kruger D, Beekes M: Widespread PrPSc accumulation in muscles of hamsters orally infected with scrapie. EMBO Rep 2003, 4:530-533

73. Andréoletti O, Simon S, Lacroux C, Morel N, Tabouret G, Chabert A, Lugan S, Corbiere F, Ferre P, Foucras G, Laude H, Eychenne F, Grassi J, Schelcher F: PrPSc accumulation in myocytes from sheep incubating natural scrapie. Nat Med 2004, 10:591-593

74. Saraswathi P: Neurohistological observations on the tongue of the monkey (Macaca radiata). J Anat Soc India 2003, 52:7-12

75. Williams ES: Chronic wasting disease. Vet Pathol 2005, 42:530-549

76. Morris JA, Gajdusek DC, Gibbs CJ Jr: Spread of scrapie from inoculated to uninoculated mice. Proc Soc Exp Biol Med 1965, 120:108-110

77. Spraker TR, Zink RR, Cummings BA, Sigurdson CJ, Miller MW, O'Rourke KI: Distribution of protease-resistant prion protein and spongiform encephalopathy in free-ranging mule deer (Odocoileus hemionus) with chronic wasting disease. Vet Pathol 2002, 39:546-556

78. Spraker TR, Zink RR, Cummings BA, Wild MA, Miller MW, O'Rourke $\mathrm{KI}$ : Comparison of histological lesions and immunohistochemical staining of proteinase-resistant prion protein in a naturally occurring spongiform encephalopathy of free-ranging mule deer (Odocoileus hemionus) with those of chronic wasting disease of captive mule deer. Vet Pathol 2002, 39:110-119

79. Karita M, Matsumoto S, Kamei T, Shinohara K, Sugiyama T: Direct transmission of $\mathrm{H}$. pylori from challenged to nonchallenged mice in a single cage. Dig Dis Sci 2005, 50:1092-1096

80. Botten J, Mirowsky K, Ye C, Gottlieb K, Saavedra M, Ponce L, Hjelle B: Shedding and intracage transmission of Sin Nombre hantavirus in the deer mouse (Peromyscus maniculatus) model. J Virol 2002, 76:7587-7594

81. Haley NJ: Detection of CWD prions in urine and saliva of deer by transgenic mouse bioassay. PLoS One 2009, 4:e4848

82. Safar JG, Lessard P, Tamguney G, Freyman Y, Deering C, Letessier F, Dearmond SJ, Prusiner SB: Transmission and detection of prions in feces. J Infect Dis 2008, 198:81-89

83. Miller MW, Williams ES, Hobbs NT, Wolfe LL: Environmental sources of prion transmission in mule deer. Emerg Infect Dis 2004, 10:1003-1006

84. Hamir AN, Gidlewski T, Spraker TR, Miller JM, Creekmore L, Crocheck M, Cline T, O'Rourke KI: Preliminary observations of genetic susceptibility of elk (Cervus elaphus nelsoni) to chronic wasting disease by experimental oral inoculation. J Vet Diagn Invest 2006, 18:110-114 